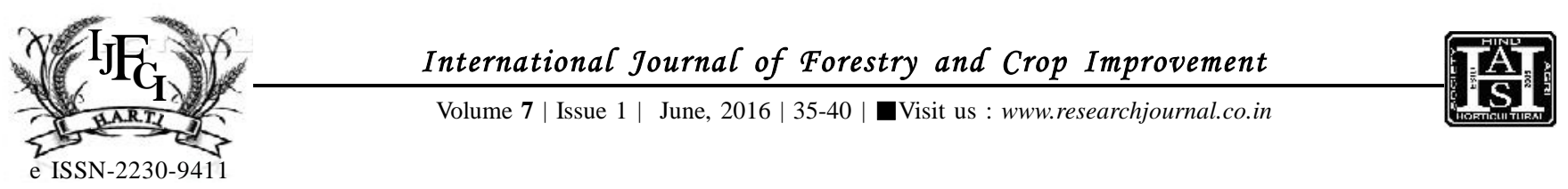

RESEARCH ARTICLE

DOI: $10.15740 / \mathrm{HAS} / \mathrm{IJFCI} / 7.1 / 35-40$

\title{
Economic evaluation of multi purpose tree species in degraded lands of Karnataka
}

\author{
S.M. Mutanal, H.Y. PATIL and M.V. MoKaShi
}

\begin{abstract}
A field experiment was conducted to know the economically viable trees on degraded lands at MARS, UAS, Dharwad under rainfed conditions. Nine trees viz., Eucalyptus tereticornis, Tectona grandis, Dalbergia sissoo, Anogeissus latifolia, Albizia lebbeck, Grevillea robusta, Hardwickia binnata, Acacia nilitica and Azadirachta indica were planted at $2 \times$ $2 \mathrm{~m}$ with three replications in Randomized Block Design. Among the tree species, total biomass was higher in Albizia lebbeck followed by Eucalyptus tereticornis and Grevillea robusta. Soil physical properties like bulk density significantly decreased in Dalbergia sissoo, Anogeissus latifolia, Albizia lebbeck and Hardwickia binnata. Trees have reduced $\mathrm{pH}$ of soil compared to open conditions. The available nitrogen, phosphorus and potassium were higher in soil grown with tree canopy of Albizia lebbeck, Hardwickia binnata and Tectona grandis, respectively. The gross return, B : C ratio and IRR were higher in Tectona grandis (Rs. 31,647/ha/yr, 4.71 and $22 \%$, respectively) followed by Eucalyptus tereticornis (Rs. 22,547/ha/yr, 3.52 and $21 \%$, respectively) as compared to other tree species.
\end{abstract}

KEY WORDS : Degraded lands, Economical, Viability, Biomass, Soil physical properties

HOW TO CITE THIS ARTICLE : Mutanal, S.M., Patil, H.Y. and Mokashi, M.V. (2016). Economic evaluation of multi purpose tree species in degraded lands of Karnataka. Internat. J. Forestry \& Crop Improv, 7 (1) : 35-40, DOI: 10.15740/HAS/IJFCI/7.1/35-40.

Article Chronical : Received : 09.02.2016; Revised : 08.04.2016; Accepted : 09.05.2016

\section{MEMBERS OF RESEARCH FORUM}

Address of the Correspondence : S.M. MUTANAL, All India Co-ordinated Research Project on Agroforestry, University of Agricultural Sciences, DHARWAD (KARNATAKA) INDIA

Email: mutanalsm@uasd.in

Address of the Coopted Authors : H.Y. PATIL and M.V. MOKASHI, All India Coordinated Research Project on Agroforestry, University of Agricultural Sciences, DHARWAD (KARNATAKA) INDIA 